\title{
Intertidal migration by the shore crab Carcinus maenas
}

\author{
E. Hunter*, E. Naylor \\ School of Ocean Sciences, University of Wales at Bangor, Marine Science Laboratories, Menai Bridge, Anglesey, \\ Gwynedd LL59 5EY, United Kingdom
}

\begin{abstract}
Intertidal migration by the shore crab Carcinus maenas (L.) was studied on a seasonal and tidal basis from May to December 1992 on Ynys Faelog, Menai Strait, North Wales, UK. Work was carried out using a specially designed, remotely operated, unbaited directional trap, in conjunction with other conventional methods. Highly oriented migration was detected, with significantly more crabs taken in traps facing up- and downshore tidal flow than when facing against or $90^{\circ}$ to flow. Facing-flow $\mathrm{crab}$ catches from falling tides were greater than those from rising tides. No significant differences were found in the numbers of daytime and nighttime migrants. Green (early intermoult) crabs were more attracted to bait than were red (late intermoult) crabs, food searching activity being extensive during times of flood tide, and rare during ebb tides. Most crabs caught in the unbaited trap were green male early intermoults, and they were retrieved more abundantly from the top half of the shore; female crabs were virtually absent from the lower shore. Upper-shore migrants were smaller than lower-shore migrants, which contained a higher proportion of late intermoult red crabs. Crabs remaining on the shore at low tide were smaller than high-tide migrants; nearly all were green and they were located most abundantly around the midshore. Numbers of both resident and migrant crabs declined between summer and winter.
\end{abstract}

\section{INTRODUCTION}

The common shore crab Carcinus maenas (L.) can be collected by hand from British shores at low tide during most of the warmer months of the year (Edwards 1958, Naylor 1962, Crothers 1968), but it also ranges subtidally to various depths dependent on locality (Chumley 1918, Broekhuysen 1936, Naylor 1962). Accordingly, although primarily an inshore, intertidal species, the shore crab has also long been recognised as an intertidal migrant, both on a tidal (Edwards 1958, Naylor 1962, Crothers 1968, Ropes 1968, Klein Breteler 1976, Dare \& Edwards 1981, Warman et al. 1993), and on a seasonal basis (Naylor 1962, Crothers 1968, Welch 1968, Atkinson \& Parsons 1973). Furthermore, it has been suggested that there are intraspecific differences in such migratory behaviour dependent upon size

\footnotetext{
- Present address: School of Biological Sciences, University College Swansea, Singleton Park, Swansea, West Glamorgan SA3 $4 \mathrm{AE}$, UK
}

(Naylor 1962) and moult stage (Warman et al. 1993). Such differences partly explain the conclusions of Crothers (1968), that some crabs remain permanently hidden on the shore at low tide, others forage intertidally on the flood tide, and retreat with the ebb, and others remain permanently below low-water mark (LWM). However, a limitation of much of the earlier work on C. maenas intertidal migrations is that co.lections at high tide were obtained mainly by the use of baited creels. Crabs are variably attracted to bait according to their moulting and hunger state, and attracted specimens may be diverted from preferred migratory routes.

The first direct study of the extent and magnitude of movements by shore crabs on a tidal basis was carried out by Dare \& Edwards (1981) using underwater video to record Carcinus maenas up and downshore migration on a mud flat in North Wales, UK. During peak times of activity, up to 130 individuals were observed passing under the camera during a period of $5 \mathrm{~min}$ on a rising tide. Concurrent observations by divers reported foraging up to $150 \mathrm{~m}$ horizontally above 
LWM, suggesting that crabs were undertaking return journeys of up to $400 \mathrm{~m}$. However, that work was undertaken only during the summer months in the hours of daylight with the camera positioned on the lower shore. Moreover, the experimental rationale included funnel-shaped netting walls $15 \mathrm{~m}$ in length and with $15 \mathrm{~m}$ wide openings, which guided crabs from upshore and downshore catchment areas, therefore laterally moving crabs were unsampled.

In a further attempt to make direct observations on the migratory behaviour of Carcinus maenas, Warman et al. (1993) used SCUBA diving to observe crabs during repeated traverses up and down the shore over the entire tidal cycle. This study suggested that small crabs (<35 mm carapace width) tended to remain within the intertidal throughout the tidal cycle, whereas large, predominantly red-coloured individuals in prolonged intermoult tended to remain in the sublittoral. In contrast, green-coloured, particularly male crabs, in early intermoult and > $35 \mathrm{~mm}$ carapace width, were observed to migrate upshore on the flood tide, and downshore again on the ebb. That study, like that of Dare \& Edwards (1981) was carried out only during daytime high tides, and it was based upon hourly observations over a $2 \mathrm{~m}$ wide transect of the shore. However, it provided the observational framework which helped to form the basis for the present investigation.

In this study a detailed examination of intertidal migration by Carcinus maenas was carried out on a tidal basis, using a variety of methods to intercept migratory crabs in summer and in winter. The principal method involved the use of a remotely operated trap which worked on a directional basis, enabling the capture of migratory individuals at any stage of diel and nocturnal tidal cycles, and omitting the use of bait. A fuller understanding of the tidal migratory behaviour of $C$. maenas in the field is required in view of recent experimental studies in which endogenous clockcontrolled locomotor activity patterns in this crab have been shown to vary in relation to tides, daylight, season, moult cycle and incident light (Naylor 1985 , McGaw \& Naylor 1992, Warman et al. 1993, Reid et al. in press).

\section{METHODS}

Study site. The study site was that used by Warman et al. (1993) on an old boat slipway extending into the shallow sublittoral on the south side of Ynys Faelog, Menai Strait, North Wales (53 $13^{\prime} 42^{\prime \prime} \mathrm{N}$, $04^{\circ} 09^{\prime} 31^{\prime \prime} \mathrm{W}$ ). The slipway extends approximately $60 \mathrm{~m}$ between mean high-water mark (MHWM) and MLWM, and consists of a $4 \mathrm{~m}$ wide, flat, near-natural, boulder-free traverse, along which crabs are known to move at times of high water (Warman et al. 1993). It provided convenient areas of substratum on which the directional trap could be positioned.

On each side of the slipway the top level of the shore consisted of a narrow band of loose stones and gravel, free of algal growth, with large amounts of driftweed often stranded at HWM. This area merged into a broad, very slightly sloping band of firm sediment, with restricted algal cover. At the top of this sediment band was an area of loose stones, with a low but dense covering of Fucus vesiculosus and some Pelvetia canaliculata. Bedrock outcrops on the upper shore marked the boundary between the littoral and supralittoral zones.

The midshore was characterised by deeply creviced bedrock outcrops and boulders, covered by a thick growth of Ascophyllum nodosum where the shore began to slope more steeply. Some bedrock outcrops were also present on the lower shore, but this area consisted primarily of large boulders surrounded by increasingly extensive patches of thick, muddy sediment towards LWM. A. nodosum was still common on the upper lower shore, but this was gradually replaced by Fucus serratus, with Ulva sp. and sessile invertebrates predominating on hard substrata on the lowest levels of the exposed shore.

Sampling along the slipway was carried out at 6 stations ranging from MHWS to MLWS, spaced at around $12 \mathrm{~m}$ horizontally from each other. Stns $1 \& 2$ were located on the upper shore, Stns $3 \& 4$ on the midshore and Stns $5 \& 6$ on the lower shore.

Directional trapping. Preliminary experiments were carried out using a wooden prototype trap consisting of

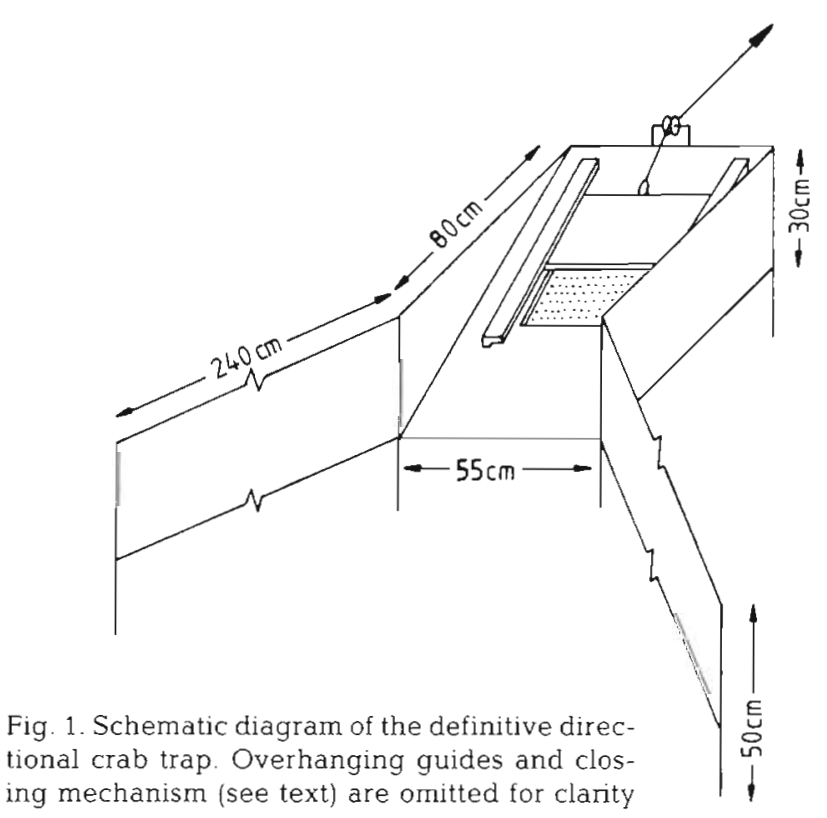


a collecting chamber into which migrating crabs were funnelled by a pair of guiding arms of $180 \mathrm{~cm}$ length and $40 \mathrm{~cm}$ height, set at $90^{\circ}$ to each other. The collecting chamber, measuring $60 \times 50 \times 30 \mathrm{~cm}$, was opened and closed remotely using a vertical sprung trapdoor mechanism. Unfortunately this proved unreliable, because of closing mechanism seizures, but 1 complete set of results was obtained and is reported below.

Most results were obtained using a directional trap constructed from a stainless steel frame measuring $80 \times 55 \times 30 \mathrm{~cm}$, with a wooden sloping top and vertical sides, and wire mesh base and back (Fig. 1). Two guide screens of stainless steel and chicken wire $\left(240 \times 30 \mathrm{~cm}\right.$, at $\left.45^{\circ}\right)$ were attached to the trap in situ, funnelling crabs to the base of the sloping top. into which the trap opening was set. Anchorage was provided by 4 sharp extensions of the frame and 2 extensions of the guide screens, which were pressed into the substratum. The trapdoor $(35 \times 18 \mathrm{~cm})$ was kept shut under the tension of 2 pieces of elasticated rope attached to the frame. This was opened by pulling on a rope attached to the top of the door which passed through a pulley to the operator upshore on dry land, where it was secured and released accordingly. Two overhanging guides placed above the trapdoor steered crabs towards the opening, and a plastic fringe was inserted over the trapdoor runners to prevent crabs from passing undermeath the guides. Also, the inside of the lip of the trap was rimmed with a $10 \mathrm{~cm}$ deep overhang which prevented crabs from escaping once inside.

The traps were positioned intertidally on 1 of the 6 stations on the Ynys Faelog slipway, the prototype being used in late May and early June 1992 and the definitive version from mid-June to December 1992. With the prototype trap, each level was sampled for one $6 \mathrm{~h}$ period facing the tidal flow during a daytime flood tide, a daytime ebb, a nighttime flood and a nighttime ebb. With the definitive version, a minimum of 8 samples were taken at each station, each with the trap open for a standard duration of $6 \mathrm{~h}$, facing the flow and against the flow during at least 1 daytime and 1 nighttime flood and ebb. In addition, the trap was also used with the opening facing across the shore at right angles to the tidal flow, at Stns $2 \& 3$.

All crabs were sexed, carapace width (CW) measured, and note was made of colouration, indicative of whether they were in early (green) or late (red) intermoult (McGaw et al. 1992). Crabs were immediately returned to the shore.

Trap data was normalised by square-root transformation and analysed as a 3-factor ANOVA (Underwood 1981), with the 3 experimental factors TIDE (flood/ebb), TIME (day/night) and STATION (Stns 1 to 6). The statistical significance of facing-flow, against- flow and across-flow crab catches were then compared using a Scheffe multiple paired comparison test.

Twenty-four hour sampling between tidemarks. In addition to directional trapping on the shore, crab movements near the slipway site were followed on 2 occasions from a small boat, on 7 to 8 and 14 to 15 July. At each sampling site, the boat was anchored on a line from the shore, with buoys marking out the 6 experimental stations. Starting at 09:00 h from Stn 6, 2 drop nets, each baited with a single mackerel, were lowered for $5 \mathrm{~min}$, and all crabs caught therein numbered, sexed, CW measured and colour noted. Sampling was carried out over each station covered by the tide, and nets were lowered every hour, on the hour, for a period of $25 \mathrm{~h}$, always commencing with Stn 6 .

Twenty-four hour sampling below tidemarks. Although Stn 6 was effectively subtidal during boat work, a permanently subtidal site was also sampled over periods of $25 \mathrm{~h}$ from the adjacent Menai Bridge pontoon pier, which rises and falls with the tide. A single drop net, baited with mackerel, was left in place for periods of $5 \mathrm{~min}$ from the time of contact with the bottom. Samples were obtained in this manner on 5 to 6 and 10 to 11 August.

Shore searching. For comparative purposes, on 17 to 18 July, 23 to 24 September and 10 to 11 November 1992 , each station was searched over an area of $10 \mathrm{~m}^{2}$ on each side of the slipway for crabs at low tide. All crabs of $\geq 10 \mathrm{~mm} \mathrm{CW}$ were taken into the laboratory, where they were sexed, measured and colour noted

\section{RESULTS}

\section{Prototype trap catches}

Moderate numbers of crabs were caught at all 6 tidal levels sampled, and those data are pooled in Table 1 , Stns 1 to 3 grouped as MTL-MHWS and Stns 4 to 6 as MTL-MLWS. Hence, each catch value in the table is the total of 3 sampling periods of $6 \mathrm{~h}$ each.

Despite relatively low sample sizes and unreliability of the trap, these data suggest that large numbers of predominantly male crabs move upshore with the flood, and downshore with the ebb, more abundantly so on the upper shore than on the lower shore. They also suggest that migratory crabs on the upper shore are smaller than those on the lower shore, and that overall, nighttime migrants are not more abundant than daytime migrants.

\section{Definitive trap catches}

The revised trap design proved highly efficient and reliable, catching more crabs per unit effort than the 
Table. 1 Numbers of crabs taken in the prototype trap, set facing the direction of tidal flow, at each of 6 tidal levels during the period May-June 1992. Data are pooled, with Stns 1 to 3 grouped as MTL-MHWS and Stns 4 to 6 as MTL to MLWS, so that each catch value is the total of three $6 \mathrm{~h}$ standard sampling periods under each state of the tidal and diel cycles. Values in parentheses are for male crabs

\begin{tabular}{|ccccccc|}
\hline Stn & \multicolumn{2}{c}{ Flood } & \multicolumn{2}{c}{ Ebb } & \multicolumn{2}{c|}{ Total } \\
& Day & Night & Day & Night & Total & Mean CW (mm) \\
\hline $1-3$ & $32(23)$ & $23(16)$ & $14(11)$ & $22(13)$ & $91(69 \%)$ & $39.2 \pm 1.5$ \\
$4-6$ & $25(21)$ & $9(8)$ & $14(7)$ & $21(15)$ & $69(74 \%)$ & $49.5 \pm 2.2$ \\
Total & $57(44)$ & $32(24)$ & $28(19)$ & $43(28)$ & $160(71 \%)$ & - \\
\hline
\end{tabular}

Table 2. Minimum, maximum and mean numbers of crabs taken in the definitive trap set facing $(n=12)$, against $(n=8)$ and $90^{\circ}(n=8)$ to up- and downshore tidal flow on Stns $2 \& 3$ during the period June-July 1992. Values are derived from standard $6 \mathrm{~h}$ samples under each state of the tidal and diel cycles

\begin{tabular}{|cccc|}
\hline & Facing & Against & $90^{\circ}$ \\
\hline Min & 2 & 1 & 0 \\
Max & 34 & 6 & 14 \\
Mean & 19.0 & 2.6 & 6.25 \\
SD & 3.1 & 0.6 & 1.8 \\
\hline
\end{tabular}

prototype model. Furthermore, because the sampling regime was standardised with $6 \mathrm{~h}$ as the basic sampling unit, direct comparisons of catches could be made. Hence, using the extensive sampling regime outlined above, a number of questions arising from the results of the prototype catches could be addressed.

Is movement orientated to up-and downshore tidal

$$
\text { flow? }
$$

This question was addressed using data from traps placed at Stns $2 \& 3$, where collections facing, against and $90^{\circ}$ to up- and downshore tidal flow were obtained. In the present study, possible neap-spring differences were not considered, but sufficient samples were obtained to randomise for tidal state and diel phase, and the numbers of crabs trapped in relation to the orientation of the trap are given in Table 2 . ANOVA suggested that significantly more crabs were taken in traps facing the tidal flow than when against or across it $(F=14.27, \mathrm{p}<0.001)$. However, a Scheffé multiple paired comparison test found that, although facing-flow catches were significantly different from against- and across-flow catches, the latter were not significantly different from each other.

Furthermore, utilising data from all stations (Table 3), crab numbers taken in traps facing the rising tide (mean $=16.9$ per 6 h sample, $n=12)$, were significantly lower than those taken in traps facing the falling tide (mean $=18.3, n=12$ ), (TIDE, $p<0.05$, Table 4), suggesting that crabs migrating downshore on the ebb tide may do so more directly than those moving upshore on the flood tide.

\section{Do night and day migrations vary in extent?}

Facing-flow catches from all levels of the shore were used to examine night-day differences in migration (Table 3). When the numbers of crabs trapped during

Table 3. Numbers of crabs taken in the definitive trap set facing the direction of tidal flow at each of 6 tidal levels during the period June-September 1992. Each value derives from a standard $6 \mathrm{~h}$ sampling period under each state of the tidal and diel cycles, with day and night flood and ebb samples at each station, all obtained within a $48 \mathrm{~h}$ period. Values in parenthesis are for male crabs

\begin{tabular}{|cccccc|}
\hline Stn Flood & \multicolumn{2}{c}{ Ebb } & Total \\
& \multicolumn{2}{c}{ Day } & Night & Day & Night \\
\hline 1 & $39(20)$ & $32(19)$ & $48(33)$ & $32(20)$ & $151(61 \%)$ \\
2 & $15(6)$ & $27(15)$ & $19(15)$ & $34(22)$ & $95(61 \%)$ \\
3 & $24(15)$ & $28(18)$ & $27(18)$ & $20(13)$ & $99(65 \%)$ \\
4 & $12(9)$ & $6(6)$ & $30(20)$ & $13(8)$ & $61(71 \%)$ \\
5 & $7(7)$ & $21(18)$ & $13(11)$ & $14(14)$ & $55(91 \%)$ \\
6 & $8(7)$ & $9(9)$ & $13(13)$ & $15(14)$ & $45(96 \%)$ \\
Total $(\%)$ & $105(61 \%)$ & $123(69 \%)$ & $150(73 \%)$ & $128(71 \%)$ & $506(69 \%)$ \\
\hline
\end{tabular}


Table 4. Comparison of crab catches taken in the definitive trap set facing the direction of tidal flow at each of 6 tidal levels during the period June-September 1992. The analysis employed was a 3-factor ANOVA, with the 3 experimental factors TIDE (flood/ebb), TIME (day/night) and STATION (Stns 1 to 6). Square-root transformation was used to normalise the data

\begin{tabular}{|lrrrrc|}
\hline Source & df & SS & MS & $F$ & $p$ \\
\hline TIDE & 1 & 1.612 & 1.612 & 11.66 & 0.019 \\
TIME & 1 & 0.002 & 0.002 & 0.02 & 0.904 \\
STN & 5 & 22.378 & 4.476 & 32.38 & 0.001 \\
TIDE $\times$ TIME & 1 & 0.740 & 0.734 & 5.35 & 0.069 \\
TIDE $\times$ STN & 5 & 2.082 & 0.416 & 3.01 & 0.126 \\
TIME $\times$ STN & 5 & 6.048 & 1.210 & 8.75 & 0.016 \\
Error & 5 & 0.691 & 0.138 & & \\
Total & 23 & 33.552 & & & \\
\hline
\end{tabular}

ebb and flood in daylight $($ mean $=21.3$ per 6 h sample; $\mathrm{n}=12$ ) were compared with those trapped during darkness $($ mean $=20.9 ; n=12$ ), no significant difference was observed (TIME, not significant, Table 4). These data demonstrate that night and day migrations did not vary in extent, although total numbers of crabs caught did vary considerably, particularly according to tidal level (STN, p >0.001, Table 4).

Is the behaviour of males and females different?

To address this question, it was again necessary to consider crab catches from all levels of the shore (Table 3). The total number of migrating individuals was found to increase 3-fold from Stn 6 at MLWS to Stn 1 at MHWS, despite the fact that the latter level of the shore was submerged for a much shorter period during high water. Assuming no sex bias in the trapping method, distinct sex differences were observed, with fewer numbers of female crabs being retained, and with virtually none captured on the lower shore (Stns $5 \& 6$ ). The number of male crabs taken was always greater, irrespective of shore level, with a sex ratio of approximately 3 male to every 2 female crabs on the upper shore. This suggests that male crabs are the predominant migratory sex in Carcinus maenas, particularly between the subtidal and low intertidal, and that upshore-migrating females do not return below about MLWN (Stn 4, Table 3).

\section{How does behaviour vary according to size?}

Data from the directional trap further demonstrate that different size classes of migratory crab were not distributed at random on the shore (Table 5). Crabs of size classes 30 to 39 and 40 to $49 \mathrm{~mm} \mathrm{CW}$ were dominant on the upper half of the shore. Large individuals were generally rare in this area, but were more prevalent from Stn 4 downwards. There was a clear shift in size distribution between Stns $4 \& 5$, crabs of 50 to $59 \mathrm{~mm} \mathrm{CW}$ being the dominant group on Stns $5 \& 6$, consistent with the view expressed above that subtidal (large) crabs move on- and offshore with each tide. Female crabs demonstrated no change in size distribution related to tidal level, again consistent with the view expressed above that migrating females are a largely intertidal population which does not extend on to the lower shore.

\section{Do crabs forage for food over the whole tidal cycle?}

Although directional trapping results indicated that there were no significant differences in nocturnal and daytime activity levels, the sampling pattern of the traps did not permit the characterisation of discrete peaks of activity at particular times of flood or ebb. Therefore, using the results from the boat sampling and Menai Pier sampling programmes, hourly foraging index (no. of crabs caught/no. of stations sampled) values were calculated. The results from two $25 \mathrm{~h}$ sampling periods were combined for each site relative to the times of high water, and are illustrated in Fig. 2. These results demonstrate that attraction to bait was

Table 5. Size groups of crabs taken in the definitive trap set facing the direction of tidal flow at each of 6 tidal levels during the period June-September 1992. Each value is derived from a standard $6 \mathrm{~h}$ sampling period under each state of the tidal and diel cycles

\begin{tabular}{|c|c|c|c|c|c|c|c|c|c|c|c|c|c|c|}
\hline \multirow[t]{3}{*}{ Stn } & \multicolumn{14}{|c|}{ Size groups (mm) } \\
\hline & \multicolumn{2}{|c|}{$10-19$} & \multicolumn{2}{|c|}{$20-29$} & \multicolumn{2}{|c|}{$30-39$} & \multicolumn{2}{|c|}{$40-49$} & \multicolumn{2}{|c|}{$50-59$} & \multicolumn{2}{|c|}{$60-69$} & \multicolumn{2}{|c|}{$70-79$} \\
\hline & $0^{\prime \prime}$ & ९ & $\sigma^{\pi}$ & & $\sigma^{\prime \prime}$ & 9 & $0^{*}$ & q & $0^{\prime}$ & $\varphi$ & $0^{7}$ & \& & $\sigma^{\prime \prime}$ & ९ \\
\hline 1 & 1 & 0 & 16 & 8 & 22 & 25 & 41 & 23 & 10 & 2 & 1 & 0 & 0 & 0 \\
\hline 2 & 0 & 0 & 5 & 7 & 29 & 32 & 37 & 10 & 8 & 1 & 4 & 0 & 1 & 0 \\
\hline 3 & 0 & 0 & 4 & 0 & 17 & 22 & 32 & 13 & 9 & 4 & 6 & 0 & 1 & 0 \\
\hline 4 & 0 & 0 & 4 & 1 & 5 & 9 & 12 & 5 & 8 & 1 & 10 & 1 & 3 & 0 \\
\hline 5 & 0 & 0 & 1 & 0 & 6 & 1 & 8 & 1 & 19 & 3 & 10 & 0 & 6 & 0 \\
\hline 6 & 0 & 0 & 2 & 1 & 2 & 0 & 7 & 0 & 16 & 1 & 8 & 0 & 5 & 0 \\
\hline
\end{tabular}




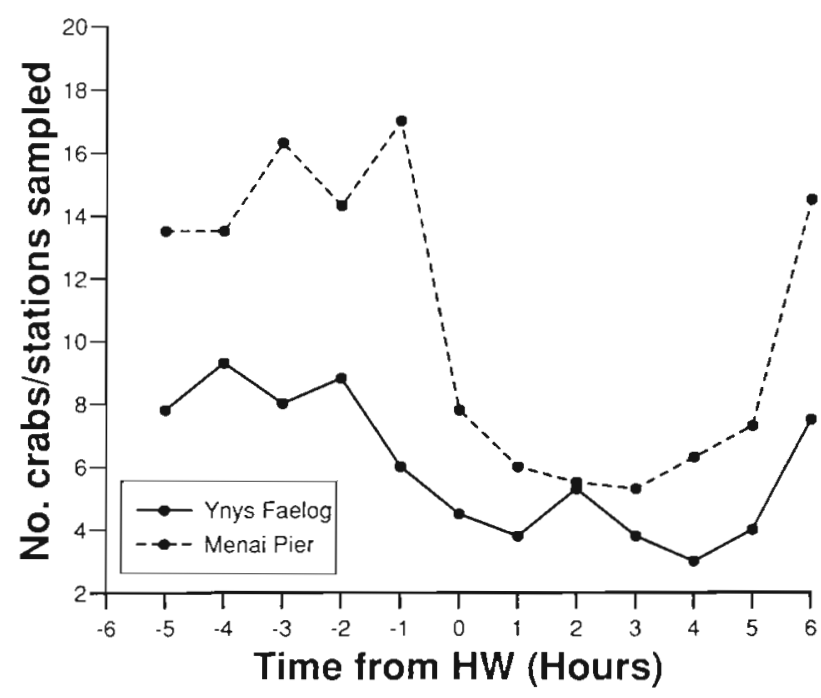

Fig. 2. Plot of hourly foraging index (no. of crabs caught/ no of stations sampled) from Ynys Faelog and Menai Bridge Pier. Data points represent the combination of results from two $25 \mathrm{~h}$ samples for each site, relative to the times of high water

extensive on the flood tide, with only minimal levels of food searching on the ebb, and are consistent with earlier findings that more crabs were caught on the ebb tide than on the flood tide. Food foraging clearly declined before the times of high water and remained low throughout most of the ebb. Moreover, the ratio of green to red crabs taken at the subtidal Menai Pier site in baited drop nets was 3.05:1 compared with 1.16:1 in the unbaited trap at Stns 5 \& 6 on Ynys Faelog (Table 6). Assuming the proportion of green:red crabs in the submerged low intertidal and shallow subtidal zones to be similar, the relatively high proportion of green crabs netted of Menai Pier suggests that bait is more attractive to intermoult crabs than to late intermoult individuals (chi-square test, $\mathrm{p}<0.001$ ).

How do size, colour and sex of crabs taken at low tide compare with those of the high-tide migrants?

In general, the majority of crabs found on the shore at low tide were small green individuals, primarily in. the size range 10 to $29 \mathrm{~mm} \mathrm{CW}$ (Table 7 ). Most resident crabs were found at Stn 3, amongst boulders on permanent bedrock. Amongst the relatively small number of larger crabs remaining on the shore at low tide, many were moulting or in mating pairs. Trapped crabs, in comparison, were of a much larger size class at all stations. The density of migrants was greater on the upper shore than at any other level, and the percentage of migrant males was very high on the lower shore. These data further confirm that during the flood tide,
Table 6. Total numbers of red and green crabs taken at the subtidal Menai Pier site in baited drop nets from two $25 \mathrm{~h}$ samples in August 1992, compared with those taken in the unbaited directional trap at Stns 5 \& 6 on Ynys Faelog during the period June-September 1992. Chi-square $=19.3$ $(p<0.001)$. O: observed : $_{\text {: expected }}$

\begin{tabular}{|lcccc|}
\hline & & Red & Green & Total \\
\hline Ynys Faelog & O & 46 & 54 & \\
& E & 27.6 & 72.4 & 100 \\
Menai Pier & O & 186 & 555 & \\
& $\mathrm{E}$ & 204.4 & 536.6 & 741 \\
Total & & 232 & 609 & 841 \\
\hline
\end{tabular}

large male crabs migrate onto the lower shore from the subtidal and that medium-sized males and females stay between tidemarks at low tide but migrate upand downshore with each tide

Red crabs were absent from the upper shore, and present only in reduced numbers at all other levels of the shore during low tide (Table 7 ). The highest proportion of resident red crabs was found at Stn 4 , which was also the area where most larger crabs were retrieved during low water. The majority of trapped crabs were also green, markedly so on the upper shore, where the proportion of green, early intermoult crabs was $>95 \%$ (Table 7). Nongreen, late-intermoult migrants increased in incidence on the lower shore, approaching a $1: 1$ green to nongreen ratio at Stn 6 . Most nongreen crabs trapped were male, female crabs being predominantly green at all levels of the shore.

A sex ratio of approximately 2 males to every female crab was found on all levels of the shore for resident crabs. It has already been noted that female migrants were largely absent from the lower shore.

Is there seasonal variation in behaviour?

In contrast to the samples taken from July to September, by November, very few crabs were retrieved from the shore at low tide (Table 8), and most of these were very small, recently settled individuals. Stn 3 was still the most densely populated area, but there was an absence of crabs from the upper shore. Nevertheless, some crabs were still involved in intertidal migration during this period, as in the summer months (see also Table 9). However, migrations were less extensive, with few individuals reaching the highest levels of the shore, and the mean size of migrants was smaller. There was an indication at this time of the year that nocturnal migrants outnumbered daytime migrants, but this difference was not statistically significant (Student's $t$-test, not significant, Table 9). 
Table 7 Comparison of density, mean carapace width (CW) and colouration of crabs present on the shore at low water, and for high-water migrants at different levels of the shore from July to September 1992 . Density of residents is given per $\mathrm{m}^{2}$, and density of migrants as mean numbers per $6 \mathrm{~h}$ sampling period

\begin{tabular}{|c|c|c|c|c|c|c|c|c|}
\hline \multirow[t]{2}{*}{ Stn } & \multicolumn{4}{|c|}{ Low tide; searching } & \multicolumn{4}{|c|}{ High tide catches } \\
\hline & No $m^{-2}$ & $\left(\begin{array}{ll}\% & \sigma^{\prime}\end{array}\right)$ & Mean CW & ( $\%$ green) & No. $(6 \mathrm{~h})^{-1}$ & $\left(\% \sigma^{*}\right)$ & Mean CW & (\% green) \\
\hline 1 & 0.2 & $(60)$ & 20.2 & $(100)$ & 37.8 & $(61)$ & 39.4 & (95) \\
\hline 2 & 2.1 & (51) & 18.5 & $(100)$ & 23.8 & (61) & 40.1 & (96) \\
\hline 3 & 7.8 & $(65)$ & 30.4 & $(100)$ & 24.8 & (65) & 43.2 & (91) \\
\hline 4 & 1.4 & (72) & 26.9 & (92) & 15.3 & (71) & 48.0 & $(76)$ \\
\hline 5 & 1.8 & (75) & 23.6 & $(94)$ & 13.8 & $(91)$ & 54.3 & (56) \\
\hline 6 & 1.9 & (61) & 24.2 & $(96)$ & 11.3 & $(96)$ & 54.5 & (51) \\
\hline
\end{tabular}

Table 8. Comparison of crabs present on the shore at low water (10 to 11 November), and high water migrants from 27 October to 4 December 1992. Density of residents is given per $\mathrm{m}^{2}$; density of migrants as mean numbers per 6 h sampling period

\begin{tabular}{|c|c|c|c|c|c|c|c|c|}
\hline \multirow[t]{2}{*}{ Stn } & \multicolumn{4}{|c|}{ Low tide searching } & \multicolumn{4}{|c|}{ High tide; catches } \\
\hline & No. $\mathrm{m}^{-2}$ & $\left(\% \sigma^{7}\right)$ & Mean CW & (\% green) & No. $(6 h)^{-1}$ & $\left(\begin{array}{lll}\% & \sigma^{\prime}\end{array}\right)$ & Mean CW & ( $\%$ green) \\
\hline 1 & 0 & - & - & - & 2.0 & $(100)$ & 37.3 & $(100)$ \\
\hline 2 & 0 & - & - & - & 17.0 & $(71)$ & 40.0 & $(95)$ \\
\hline 3 & 2.4 & (92) & 30.8 & $(92)$ & 12.0 & (71) & 42.4 & $(96)$ \\
\hline 4 & 0.4 & (50) & 15.3 & $(50)$ & 11.0 & (73) & 40.1 & (93) \\
\hline 5 & 0 & - & - & - & 5.0 & (90) & 43.6 & (93) \\
\hline 6 & 0.1 & $(0)$ & 19.0 & $(0)$ & 5.0 & $(100)$ & 48.7 & (58) \\
\hline
\end{tabular}

\section{DISCUSSION}

The present sampling programme, using unbaited traps over the complete diel cycle in summer and winter, is a much less biased procedure than those used hitherto to investigate the intertidal migratory behaviour of the crab Carcinus maenas. Accordingly, though present results confirm the results of some earlier studies, a need for the revision and refinement of many earlier findings is apparent.

Present and earlier studies (Naylor 1962, Crothers 1968, Warman et al. 1993) now unequivocally confirm that small crabs, those in the present study of

Table 9. Numbers of crabs taken in the definitive trap at each of 6 tidal levels during the period October-December 1992. Each value is based on a standard $6 \mathrm{~h}$ sampling period. Data recorded from flood tides only. Values in parentheses are for male crabs

\begin{tabular}{|crrrrrr|}
\hline Stn & \multicolumn{2}{c}{ Day } & \multicolumn{2}{c}{ Night } & \multicolumn{2}{c|}{ Total } \\
\hline 1 & 1 & $(1)$ & 3 & $(3)$ & 4 & $(100 \%)$ \\
2 & 6 & $(4)$ & 28 & $(20)$ & 34 & $(71 \%)$ \\
3 & 8 & $(6)$ & 16 & $(11)$ & 24 & $(71 \%)$ \\
4 & 12 & $(9)$ & 10 & $(7)$ & 22 & $(73 \%)$ \\
5 & 5 & $(5)$ & 5 & $(4)$ & 10 & $(90 \%)$ \\
6 & 5 & $(5)$ & 5 & $(5)$ & 10 & $(100 \%)$ \\
Total & 37 & $(30)$ & 67 & $(50)$ & 104 & $(77 \%)$ \\
\hline
\end{tabular}

$<30 \mathrm{~mm}$ CW, remain between tidemarks over all states of tide and throughout the year. In these first-year crabs, unlike larger migratory forms, it has been shown (Reid et al. in press) that their endogenous circatidal rhythms of locomotor activity can be entrained by cycles of emersion and immersion, consistent with their repeated exposure to such events on the shore. Present data also confirm that in summer, and to a lesser extent in winter, there is a large population of intertidal migrants (Naylor 1962, Crothers 1968, Dare and Edwards 1981) many of which are green, early intermoult males (Warman et al. 1993). However, the greater sampling intensity employed here permits considerable refinement of those earlier interpretations. At the present sample site, virtually all the crabs migrating to the top of the shore were green early-intermoult forms, but they consisted of males : females at the ratio of 1.86:1, and these moved downshore only as far as the midtidal zone on the ebb. Those crabs migrating on and off the lower shore at high tide did so from below the tidemarks. They were larger than the high-shore migrants, were virtually all male, and included lateintermoult red crabs and green crabs at a ratio of approximately 4:6. Hence, there appeared to be a 'ladder-like' form of upshore migration, with subtidal forms displacing onshore forms as the tide flooded, with the reverse pattern occurring on the ebb, in a manner which appears not to have been reported previously. 
It is clear that green, early-intermoult males, are the most likely individuals to perform up-and downshore migrations, sometimes remaining between tidemarks at low tide and sometimes remaining below tidemarks. Certainly it is these individuals amongst the larger crabs (>35 mm CW) which exhibit the most persistent endogenous circatidal rhythms of locomotor activity (Naylor 1958, Atkinson \& Parsons 1973). These are probably the most actively feeding individuals (Warman et al. 1993) and present results clearly show that they are attracted to bait on the flood tide but not on the ebb. It remains to be investigated experimentally whether such apparent changes in feeding behaviour occur as a response to feeding, or whether they occur spontaneously, as in the case of the crab's orientational responses to light (Warman et al. 1993).

Finally, a further particularly interesting finding in the present study is that tidally migrant Carcinus maenas were caught as abundantly by day as by night. This is surprising in view of the fact that in the expression of free-running rhythms of locomotor activity in the laboratory, C. maenas shows greater activity at times of expected nocturnal high tides than at expected daytime high tides (Naylor 1958). This raises further questions about the functional partitioning of locomotor activity patterns in $C$. maenas. The ecological significance of increased nocturnal activity which is driven by circadian rhythmicity independent of the circatidal rhythm (Naylor 1985) remains so far unexplained.

Acknowledgements. We are grateful to the Wolfson Foundation for funding this work. Martin Essen and Elwyn Jones designed and built the traps. Gwynne Jones provided invaluable assistance in the field, and Dr P. Abelló, T Wong, C. Zeng, A. P. Tharme, J. Sharples and C. A. Rant volunteered long hours to help in the collection of field data. Drs P. Abelló, C. G. Warman and D.G. Reid provided helpful discussion and advice.

\section{LITERATURE CITED}

Atkinson, R. J. A., Parsons, A. J. (1973). Seasonal patterns of migration and locomotor rhythmicity in populations of Carcinus. Neth. J. Sea Res. 7: 81-93

This article was submitted to the editor
Broekhuysen, G. J. (1936). On the development, growth and distribution of Carcinides maenas (L.). Arch. neerl. Zool. 2: $258-399$

Chumley, J. (1918). The fauna of the Clyde Sea area. Glasgow Univ. Press, Glasgow

Crothers, J. H. (1968). The biology of the shore crab Carcinus maenas (L.) 2. The life of the adult crab. Fld Studies 2(5): $579-614$

Dare, P. J., Edwards, R. L. (1981). Underwater television observations on the intertidal movements of shore crabs Carcinus maenas, across a mudflat. J. mar. biol. Ass. U.K. 61: $107-116$

Edwards, R. L. (1958). Movements of individual members in a population of the shore crab, Carcinus maenas (L.), in the littoral zone. J. Anim. Ecol. 27: 37-45

Klein Breteler, W. C. M. (1976). Migrations of the shore crab Carcinus maenas in the Wadden sea. Neth. J Sea Res. 10(3): 338-353

McGaw, I. J., Kaiser, M. J., Naylor, E., Hughes, R. N. (1992) Intraspecific morphological variation related to the moultcycle in colour forms of the shore crab Carcinus maenas. J. Zool., Lond. 228: 351-359

McGaw, I. J., Naylor, E. (1992). Distribution and rhythmic locomotor patterns of estuarine and open-shore populations of Carcinus maenas. J. mar. biol. Ass. U.K. 72 599-609

Naylor, E. (1958). Tidal and diurnal rhythms of locomotor activity in Carcinus maenas (L.). J. exp. Biol. 35: 602-610

Naylor, E. (1962). Seasonal changes in a population of Carcinus maenas ( $\mathrm{L}$.) in the Littoral zone. J. Anim. Ecol. 31 601-609

Naylor, E. (1985). Tidally rhythmic behaviour of marine animals. Symp. Soc exp. Biol. 39: 63-93

Reid, D. G., Warman, C. G., Naylor, E. (1993). Ontogenetic changes in zeitgeber action in the tidally rhythmic behaviour of the shore crab Carcinus maenas. Proc. 27th Eur mar. biol. Symp. (in press)

Ropes, J. W. (1968). The feeding habits of the green crab Carcinus maenas (L.). Fishery Bull. Fish Wildl. Serv. U.S. $67(2): 183-203$

Underwood, A. J. (1981). Techniques of analysis of variance in experimental marine biology and ecology. Oceanogr. mar. biol. A. Rev. 19: 513-605

Warman, C. G., Reid, D. G., Naylor, E. (1993). Intraspecific variation in the tidal migratory behaviour \& associated rhythmic responsiveness to directional light in the shore crab Carcinus maenas. J. mar. biol. Ass. U.K. 73: in press

Welch, W. R. (1968). Changes in abundance of the green crab Carcinus maenas (L.) in relation to recent temperature changes. Fishery Bull. Fish Wildl. Serv. U.S. 67(2): $337-345$

Manuscript first received: March 1, 1993

Revised version accepted: July 22, 1993 